\author{
두충잎의 급여가 면양의 영양소 이용율과 \\ 반추위내 발효특성에 미치는 영향 \\ 김재황* · 고영두** \\ 한국응용미생물산업연구소*, 경상대학교 농업생명과학대학**
}

\title{
Effects of Dietary Eucommia ulmoides Leaves on Nutrient Digestibility and Ruminal Fermentation Characteristics in Sheep
}

\author{
J. H. Kim* and Y. D. Ko** \\ Korea Applied Microorganism Industrial Research*, College of Agriculture and Life Science, \\ Gyeongsang National University**
}

\begin{abstract}
This study was conducted to examine the nutrient digestibility and ruminal fermentation characteristics in sheep fed diets containing four substitution levels of E. ulmoides leaves for rice straw. For the experiment, they were given a basal diet consisting of rice straw and concentrate at a 3:7 ratio (DM basis). The treatments were designed as a $4 \times 4$ Latin square design with four sheep $(50.2 \pm 1.6 \mathrm{~kg}$ body weight). Sheep were allotted in one of four treatments, which were designed to progressively substitute Eucommia ulmoides for $0,3,5$ and $10 \%$ of rice straw in the basal diet. The digestibility of crude fat was significantly $(\mathrm{p}<0.05)$ improved by 12.5 to $17.5 \%$ in $3 \%$ and $5 \%$ air dried Eucommia ulmoides leaves compared with that in control. The digestibility of crude fiber in the 3, 5 and $10 \%$ treatments was significantly $(\mathrm{p}<0.05)$ higher than that of the control. Dry matter intake was highest $(\mathrm{p}<0.05)$ in sheep fed $10 \%$ air dried E. ulmoides). Retained nitrogen in the 3, 5 and $10 \%$ treatments was increased up to $97 \%$, $173 \%$ and $192 \%$, respectively, compared to that in control $(\mathrm{p}<0.05)$. Organic matter utilization was higer in $3 \%$ and $5 \%$ treatments than control $(\mathrm{p}<0.05)$. Purine derivatives and microbial nitrogen synthesis were significantly increased by the dietary substitution of $5 \%$ E. ulmoides leaves $(p<0.05)$ compared with control and the $3 \%$ treatment. Ruminal concentration of total-VFA was significantly $(p<0.05)$ higher in sheep fed all levels of air dried Eucommia ulmoides than those of control.

It is concluded that air-dried E. ulmoides leaves given to ruminants can increase nutrient digestibility and palatability and improve ruminal fermentation. Therefore, the 5 and $10 \%$ substitution of E. ulmoides for roughage are highly recommended to be used in practice.
\end{abstract}

(Key words : Eucommia ulmoides, Dry matter intake, Digestibility, Ruminal fermentation, Microbial nitrogen)

Corresponding author : Y. D. Ko, Animal Science Major, Division of Animal Science and Technology, College of Agriculture and Life Science, Gyeongsang National University Jinju, 660-701, Korea. Tel : 055-751-5512, E-mail : ydko@nongae.gsnu.ac.kr 


\section{I. 서 론}

두충(학명: Eucommia ulmoides OLIVER)은 두 충과(Eucommiaceae)에 속하는 낙엽 교목(喬木) 으로서 세계 1속 1종으로 30 년생은 높이가 $20 \mathrm{~m}$ 에 달하며 우리나라에서는 1930년 이후 재 배되고 있으며, 두충 잎은 조단백질 $20 \%$, 조지 방 $7 \%$, 조섬유 $20 \%$ 및 NFE $46 \%$ 로서 높은 조 단백질 함량은 사료가치 측면에서 우수하다. 두충은 지금까지 알려진 가장 오래된 약용 식 물 중의 하나로서 두충 잎에는 alkaloid, 지질, 유기산, 당류 및 vitamin $\mathrm{C}$ 등이 함유(Deyama 등, 1987)되어 있으며, 혈압 강하작용을 하는 phenol성 화합물인 pinoresinol diglucoside의 약효성분이 함유되어 있을 뿐만 아니라 다양 한 생리활성 물질이 함유되어 있어 혈압강하 (Metori 등, 1997), 항당뇨 활성(Hwang 등, 1996), cholesterol 저하 및 비만 방지(Nakasa 등, 1995) 등 에 효과가 있는 것으로 알려져 있다. 수피는 보정 (補精), 이뇨(利尿) 및 강근골(强筋骨) 등의 작용이 인정되어 한방에서는 강장제(强壯齋)로 사용하고 있으며 잔가지(ramulus)도 처방에 따라서 소량 사 용하고 있고, 최근 잎은 건강보조식품인 차로 가 공하여 널리 보급되고 있다(박과 김, 1996).

그러나 최근 값싼 중국산 두충의 수입으로 국내 한약재는 시장경쟁력을 잃게 되었으며, 자 원활용 측면에서도 제한되어 그 이용성이 현저 하게 낮을 뿐 만 아니라 두충의 원가 하락으로 농가의 재배의옥 저하로 산야에 방치되거나 벌 목되고 있는 실정이므로 두충의 활용성을 높일 수 있는 연구가 절실히 요구되고 있다.

이상과 같이 현재까지 두충의 약리적 효과에 대한 많은 관심으로 인해 동의보감 등 고문헌 에서도 혈압 강하, 비만 방지 및 이뇨 효과를 다루고 있을 뿐만 아니라 다양한 연구들이 진 행되어 온 바, 대부분의 연구들이 인체에 적용 하기 위한 생약분야의 연구들이었으며 동물에 대한 연구는 극히 미비하고, 특히 두충의 활용 방안 뿐만 아니라 생리활성 물질에 의한 가축 의 질병예방 효과, 스트레스 경감, 사료의 이용 율 개선 및 분뇨의 악취 저감 등에 관한 연구 는 전무한 상태이다.
따라서 본 연구는 생리활성물질 등 약리효과 가 함유된 두충 잎을 반추동물의 조사료원으로 이용할 목적으로 두충 잎을 채취하여 음건한 후 건물기준으로 대조구(볏짚)에 3, 5 및 $10 \%$ 를 대체한 사료를 시험사료로 하여 반추동물의 영양소 이용율 등 사료적 가치를 평가하기 위 하여 영양소 소화율, 건물섭취량, 질소출납과 미생물체 단백질 합성량 및 반추위 내 발효특 성을 구명하였다.

\section{II. 재료 및 방법}

\section{1. 시험기간 및 장소}

시험기간은 2004년 7월부터 6개월간 실시하 였으며, 대사시험은 경상대학교 부속동물시험 장에서, 채취한 시료의 분석은 본 대학 동물영 양학 연구실에서 실시하였다.

\section{2. 공시동물, 시험사료 및 사양관리}

평균체중 $50.2 \pm 1.6 \mathrm{~kg}$ 의 건강한 수 면양(Corriedale $\times$ Polwarth) 4 두로 $4 \times 4$ 라틴 방격법으로 실시하 였으며, 본 시험에 이용된 볏짚, 농후사료 및 두 충 잎의 화학적 조성은 Table 1과 같으며, 두충 은 경남 진주시 이반성면 인근 야산의 두충 군 락지에서 채취하여 음건한 것을 분쇄기(hammer mill)로 분쇄 $(5 \mathrm{~mm}$ screen)하여 시험에 이용하였 다. 사료는 오전과 오후 2 회로 나누어 급여하 였으며(09시와 17시), 총 사료급여량은 면양 체 중의 $2 \%$ 로 조절하여 급여하였으며, 음수는 자 유로이 먹을 수 있게 하였으며, 비타민과 무기 물의 공급을 위해 mineral block을 급여하였다. 시험사료는 볏짚과 농후사료를 기초사료로 조 : 농 비율을 $7: 3$ 이 되게 하여 급여하였다. 시 험구는 두충 잎을 대체하지 않은 대조구와 조 사료인 볏짚의 건물을 기준으로 음건 두충 잎 을 3, 5 및 $10 \%$ 대체한 4 개 처리구로 급여하였 다. 예비시험을 10 일간, 본 시험으로 대사시험 5 일, 사료섭취량 측정 1 일, 반추위내 발효특성 측정 1 일 6 회(사료 급여 전 0 시간 및 사료 급 여 후 $0.5,1,2,4$ 및 8 시간)를 수행하였다. 
Table 1. Chemical composition (\% DM, unless stated otherwise) of rice straw, concentrate and Eucommia ulmoides leaves

\begin{tabular}{|c|c|c|c|c|}
\hline Items & Concentrate & Rice straw & $\begin{array}{c}\text { Eucommia } \\
\text { ulmoides }\end{array}$ & SEM \\
\hline Dry matter (\%) & 87.82 & 88.53 & 89.81 & 0.544 \\
\hline Crude protein & $17.29^{\mathrm{b}}$ & $4.22^{\mathrm{c}}$ & $19.53^{\mathrm{a}}$ & 0.710 \\
\hline Ether extract & $4.49^{\mathrm{b}}$ & $1.64^{\mathrm{c}}$ & $6.83^{\mathrm{a}}$ & 0.648 \\
\hline Crude fiber & $3.67^{\mathrm{c}}$ & $28.28^{\mathrm{a}}$ & $20.36^{\mathrm{ab}}$ & 1.205 \\
\hline Crude ash & $6.19^{\mathrm{b}}$ & $10.97^{\mathrm{a}}$ & $7.02^{\mathrm{b}}$ & 0.882 \\
\hline Neutral detergent fiber & $31.05^{\mathrm{c}}$ & $66.53^{\mathrm{a}}$ & $49.35^{\mathrm{b}}$ & 0.942 \\
\hline Acid detergent fiber & $15.99^{\mathrm{c}}$ & $47.48^{\mathrm{a}}$ & $44.36^{\mathrm{b}}$ & 0.754 \\
\hline Nitrogen free extract & $68.46^{\mathrm{a}}$ & $54.89^{\mathrm{b}}$ & $46.26^{\mathrm{c}}$ & 0.998 \\
\hline
\end{tabular}

a, b, c Means with different superscripts in the same row differ significantly $(\mathrm{p}<0.05)$.

\section{3. 조사항목 및 분석방법}

\section{(1) 시료의 채취 및 분석}

영양소 소화율 측정을 위해 시료를 5일간 수 거하여 무게를 측정한 후, 무게비율에 따라 약 $100 \mathrm{~g}$ 을 분석용으로 채취하였으며, $65^{\circ} \mathrm{C}$ 송풍건 조기에서 72시간 건조시켜 hammer mill로 $1 \mathrm{~mm}$ screen을 통과한 시료를 분석용으로 사용하였다. 질소 출납을 위한 뇨의 수집은 암모니아 가스의 휘산을 방지하기 위해 약 $15 \mathrm{ml}$ 의 진한 황산을 수집용기에 넣어 뇨 배설량을 측정한 후 가아제 로 걸러 $-20^{\circ} \mathrm{C}$ 에서 분석시까지 냉동보관 하였다. 일반성분 분석은 $\mathrm{AOAC}$ 법(1990), $\mathrm{NDF}$ 와 $\mathrm{ADF}$ 함 량 분석은 Van Soest 등(1991)에 준하였다.

\section{(2) 반추위액의 채취 및 분석}

반추위 내 발효특성의 조사는 면양의 경구를 통 하여 stomach tube를 주입하여 약 $100 \mathrm{ml}$ 의 위액을 채취하였으며 $(0,0.5,1,2,4$ 및 8 시간), 채취된 위 액은 4겹 cheese cloth로 걸러 glass rod electric $\mathrm{pH}$ meter를 이용하여 즉시 $\mathrm{pH}$ 를 측정한 후 위액의 발 효를 방지하기 위해 $\mathrm{HgCl}_{2}$ 를 6 7방울을 투입하 여 분석시까지 $-25^{\circ} \mathrm{C}$ 에서 냉동보관 하였다.

암모니아태 질소와 총 휘발성지방산의 측정은 냉동 보관된 시료를 실온에서 해동하여 $3,000 \mathrm{rpm}$ 에서 10 분간 원심분리 후 상층액을 분석용으로 이용하였다. 반추위액의 암모니아태 질소 함량은 森本(1971)법, 총 휘발성지방산 함량은 Fenner와 Elliot 증류법(1963)에 준하여 GC(Hewlett Packard GC-5890 series II)를 이용하였다.
(3) 사료섭취량 및 미생물체단백질 합성량

사료섭취량 시험은 소화시험 종료 후 각 구 당 1 두씩 배치하여 1 회에 15 분씩 3 시간 간격으 로 1일 3회 조사하였다(森本, 1971). 미생물체단 백질 합성량을 측정하기 위하여 소화시험 기간 중 분과 뇨를 전량 수집하였으며, 수집 중 뇨 의 $\mathrm{pH}$ 를 3.0 이하로 유지하기 위하여 약 $15 \mathrm{ml}$ 의 진한 황산을 첨가하였다. 분석을 위하여 약 $100 \mathrm{ml}$ 의 시료를 취하여 4겹의 cheese cloth로 걸렀으며, 보관 중에 결정이 생성되는 것을 방 지하기 위하여 증류수로 4 배 희석한 후 $-20^{\circ} \mathrm{C}$ 에서 보관하였다. 분석을 위해 해동 후 다시 뇨 원액을 기준으로 50 배 희석하여 분석에 이 용하였다(Chen과 Gomes, 1995).

\section{4. 통계처리}

본 시험에서 얻어진 결과는 $\operatorname{Excel(2000)ㅇㅡㄹ~ㅇㅣㅇㅛㅇ~}$ ·정리하여 SAS package(1990)의 Annova procedure 로 분석 하였으며, 이들의 평균값을 이용하여 Duncan's multiple range test(Duncan, 1955)로 처 리간 유의차 검정을 실시하였다.

\section{III. 결과 및 고찰}

\section{1. 영양소 소화율과 건물섭취량}

두충 잎을 급여하는 조사료를 기준으로 0,3 , 5 및 $10 \%$ 대체한 사료를 면양에 급여하였을 때 영양소 이용율, 가소화영양소 총량(TDN) 및 
건물섭취량을 조사한 결과는 Table 2와 같다.

건물과 조단백질 소화율은 대조구를 포함한

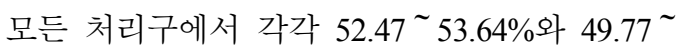
$51.86 \%$ 로서 유의차는 없었다. 조지방 소화율은 $3 \%$ 와 $5 \%$ 구에서 각각 $73.92 \%$ 와 $72.48 \%$ 로 대조 구(62.90\%)에 비하여 약 $12.5 \sim 17.5 \%$ 로 크게 증 가하였다 $(\mathrm{p}<0.05)$. 조섬유의 소화율은 대조구가 $48.36 \%$ 였으며 두충 잎을 대체한 모든 처리구 에서는 $53.49^{\sim 54.97 \%}$ 로 대조구에 비하여 약 $10.6^{\sim 13.7 \%}$ 로 크게 개선되었다 $(\mathrm{p}<0.05)$. 또한 $\mathrm{NDF}$ 와 $\mathrm{ADF}$ 소화율은 대조구가 각각 $40.12 \%$ 와 $31.92 \%$ 였으며 $10 \%$ 대체할 경우에는 각각 $45.01 \%$ 와 $36.48 \%$ 로 대조구에 비하여 크게 개 선되었다 $(\mathrm{p}<0.05)$. 그러나 $3 \%$ 구와 $5 \%$ 구와는 유의차가 없었다. 유기물 소화율은 대조구가 $52.32 \%$ 였으며 $3 \sim 5 \%$ 대체할 경우에는 53.02 $54.45 \%$ 로 대조구와는 유의차가 없었으나 $10 \%$ 대체할 경우에는 $56.43 \%$ 로 대조구에 비하여 약 $7.3 \%$ 가 개선되었다 $(\mathrm{p}<0.05)$. 가용무질소물 소화 율은 대조구를 포함한 모든 처리구에서 62.78 64.21\%로 처리구간에 유의차는 없었다. 가소 화영양소 총량 $(\mathrm{TDN})$ 은 $3 \%$ 구가 $45.20 \%$ 로 대 조구 $(42.49 \%)$ 에 비하여 약 $6.4 \%$ 가 개선되었으 며 $(\mathrm{p}<0.05), 5 \%$ 구와 $10 \%$ 구는 각각 $43.55 \%$ 와 $43.80 \%$ 로 모든 처리구간에 유의차는 없었다.

맹(1998)은 반추위내 단백질의 분해량과 분해 속도는 단백질 공급원, 제 1 위내 $\mathrm{pH}$ 및 미생물
성상에 의해 결정되는데, 다즙질 사료의 단백질 과 가용성당은 단백질분해 박테리아의 성장을 촉진시킴으로 저단백질 건초에 비해 단백질 분 해력이 높다고 하였다. 반추동물에 대한 두충 급여에 관한 연구는 전무한 상태이지만, 특히 박과 김(1996)은 두충 잎 추출물을 육계에 급여 시 혈중 콜레스테롤 농도와 glutamic oxaloacetic transaminase(GOT) 농도를 현저히 감소시키는 효 과가 있으며, $\mathrm{Hu}(1978)$ 는 두충 추출물을 쥐에 투여했을 때 간 독성을 예방하고 간 기능을 회 복시킬 뿐만 아니라 담즙산 분비를 촉진시켜 생 체내의 지질대사를 촉진시킨다고 보고하였다.

본 연구의 결과 두충 잎을 대체·급여함으로 서 섬유소 소화율이 향상되는데, 이는 두충 잎 의 $\mathrm{NDF}$ 와 $\mathrm{ADF}$ 함량이 볏짚 보다 각각 $17.18 \%$ 와 $3.12 \%$ 가 낮으므로 양질의 조사료 급여로 인 한 효과라고 생각된다.

이상의 결과, 두충 잎을 조사료에 $3 \sim 5 \%$ 대 체·급여시 조지방 소화율이 개선되며, $5 \sim 10 \%$ 대체·급여할 경우에는 섬유소 및 유기물 소화 율이 개선됨으로 소화율 개선을 위한 효과적인 대체수준이라고 생각된다.

그러나 본 연구의 경우 $10 \%$ 대체할 경우에는 지방소화율이 $65.62 \%$ 로서 $3 \sim 5 \%$ 대체할 경우보 다 낮아지는데, 이와 같이 두충을 과잉 급여시 지방소화율이 낮아지는 이유에 대해서는 보다 구 체적인 연구가 수행되어야 할 것으로 생각한다.

Table 2. Effects of dietary substitution of Eucommia ulmoides leaves for rice straw on the nutrient digestibility and feed intake (\% DM, unless stated otherwise) by sheep

\begin{tabular}{lccccc}
\hline \multirow{2}{*}{ Items } & \multicolumn{2}{c}{ Substituted levels (\%) of air dried Eucommia ulmoides leaves } & \multirow{2}{*}{ SEM } \\
\cline { 2 - 5 } & 0 & 3 & 5 & 10 & \\
\hline \hline Dry matter (\%) & 53.64 & 52.47 & 53.36 & 52.52 & 0.405 \\
Crude protein & 49.77 & 51.86 & 50.58 & 50.03 & 0.715 \\
Ether extract & $62.90^{\mathrm{b}}$ & $73.92^{\mathrm{a}}$ & $72.48^{\mathrm{a}}$ & $65.62^{\mathrm{b}}$ & 0.983 \\
Crude fiber & $48.36^{\mathrm{b}}$ & $54.15^{\mathrm{a}}$ & $53.49^{\mathrm{a}}$ & $54.97^{\mathrm{a}}$ & 0.653 \\
Neutral detergent fiber & $40.12^{\mathrm{b}}$ & $41.87^{\mathrm{b}}$ & $43.67^{\mathrm{ab}}$ & $45.01^{\mathrm{a}}$ & 0.732 \\
Acid detergent fiber & $31.92^{\mathrm{b}}$ & $33.45^{\mathrm{b}}$ & $35.37^{\mathrm{ab}}$ & $36.48^{\mathrm{a}}$ & 0.991 \\
Organic matter & $52.32^{\mathrm{b}}$ & $53.02^{\mathrm{b}}$ & $54.45^{\mathrm{ab}}$ & $56.43^{\mathrm{a}}$ & 0.705 \\
Nitrogen free extract & 63.51 & 64.21 & 63.48 & 62.78 & 0.837 \\
Total digestible nutrients & $42.49^{\mathrm{b}}$ & $45.20^{\mathrm{a}}$ & $43.55^{\mathrm{ab}}$ & $43.80^{\mathrm{ab}}$ & 0.734 \\
Dry matter intake $(\mathrm{g} / \mathrm{d})$ & $804^{\mathrm{c}}$ & $809^{\mathrm{c}}$ & $828^{\mathrm{b}}$ & $844^{\mathrm{a}}$ & 5.035 \\
Intake $(\mathrm{g}) / \mathrm{BW}(\mathrm{kg})$ & $16.02^{\mathrm{b}}$ & $16.12^{\mathrm{b}}$ & $16.49^{\mathrm{ab}}$ & $16.81^{\mathrm{a}}$ & 0.179 \\
Intake $(\mathrm{g}) / \mathrm{BW}{ }^{0.75}(\mathrm{~kg})$ & $42.63^{\mathrm{b}}$ & $42.90^{\mathrm{b}}$ & $43.90^{\mathrm{ab}}$ & $44.75^{\mathrm{a}}$ & 0.285 \\
\hline
\end{tabular}

a, b, c Means with different superscripts in the same row differ significantly $(\mathrm{p}<0.05)$. 
한편 건물 섭취량은 $10 \%$ 구가 $844 \mathrm{~g} / \mathrm{d}$ 으로 가장 많았으며 $5 \%$ 구는 $828 \mathrm{~g} / \mathrm{d}$ 으로 그 다음으 로 많이 섭취하였으며, 대조구와 $3 \%$ 구는 각 각 $804 \mathrm{~g} / \mathrm{d}$ 과 $809 \mathrm{~g} / \mathrm{d}$ 으로 가장 낮았다 $(\mathrm{p}<0.05)$. 체중당 섭취량과 대사체중당 섭취량에서도 $10 \%$ 구에서 증가하였으나 $(\mathrm{p}<0.05)$, 다른 처리구간에 는 유의차가 없었다.

특히 본 연구에 이용된 두충을 건조시킴으로 써 생 두충에 함유되어 있는 향기 성분인 정유물 질이 휘산될 뿐만 아니라 불포화 지방산의 증가 로 풍미가 개선되었으며(김, 2005), 두충에 함유 된 항균성 물질 등에 의해 영양소 소화율이 개선 (Table 2)되었기 때문에 사료섭취량이 증가된 것 으로 생각되지만 앞으로 이에 대한 세부적인 연 구를 통한 구명이 필요할 것으로 생각된다.

\section{2. 질소 출납과 미생물체단백질 합성량}

두충 잎을 급여하는 조사료를 기준으로 $0,3,5$ 및 $10 \%$ 대체한 사료를 면양에 급여하였을 때 시 험사료의 질소 출납, 유기물 섭취량, 유기물 소화 율, $\mathrm{PD}$ (purine derivatives) 배설량 및 미생물체단 백질 합성량을 조사한 결과는 Table 3 과 같다.

질소 섭취량은 $5 \%$ 구와 $10 \%$ 구가 각각 12.41 및 $12.55 \mathrm{~g} / \mathrm{d}$ 로 대조구의 $10.31 \mathrm{~g} / \mathrm{d}$ 와 $3 \%$ 구의 $10.84 \mathrm{~g} / \mathrm{d}$ 에 비해 높았다 $(\mathrm{p}<0.05)$. 그러나 분 중 질소 배설량은 대조구와 $10 \%$ 구가 각각 4.28 $\mathrm{g} / \mathrm{d}$ 및 $4.43 \mathrm{~g} / \mathrm{d}$ 로 $3 \%$ 구의 $3.57 \mathrm{~g} / \mathrm{d}$ 에 비해 높았
다 $(\mathrm{p}<0.05)$. 뇨 중 질소 배설량은 대조구가 4.38 $\mathrm{g} / \mathrm{d}$ 로 $5 \%$ 구와 $10 \%$ 구의 3.65 와 $3.33 \mathrm{~g} / \mathrm{d}$ 에 비 해 높았다 $(\mathrm{p}<0.05)$. 질소 축적량은 두충 잎을 대체수준을 증가 시킬수록 높아져서 대조구는 $1.64 \mathrm{~g} / \mathrm{d}$ 였으며 $3 \%$ 구는 $3.23 \mathrm{~g} / \mathrm{d}$ 로 약 $97 \%$ 가 개선되었으며, $5 \%$ 구와 $10 \%$ 구는 각각 4.65 와 $4.79 \mathrm{~g} / \mathrm{d}$ 로 약 $173 \sim 192 \%$ 로 크게 개선되었다 $(\mathrm{p}<0.05)$. 유기물 섭취량은 대조구를 포함한 모 든 처리구에서 $628.87^{\sim} 643.46 \mathrm{~g} / \mathrm{d}$ 로 처리구간에 유의차는 없었다. 유기물 이용율은 3\% 구와 5\% 구가 각각 $45.10 \%$ 와 $44.83 \%$ 로 대조구의 $41.54 \%$ 에 비해 높았으며 $(\mathrm{p}<0.05)$, 대체수준 간에는 차 이가 없었다. PD 배설량은 $5 \%$ 구가 $2.90 \mathrm{mmol} / \mathrm{d}$ 로 대조구의 $2.43 \mathrm{mmol} / \mathrm{d}$ 와 $3 \%$ 구의 $2.42 \mathrm{mmol} / \mathrm{d}$ 에 비해 높았다 $(\mathrm{P}<0.05)$. 미생물체단백질 합성 량은 $5 \%$ 구가 $2.51 \mathrm{gN} / \mathrm{d}$ 로 대조구의 $2.11 \mathrm{gN} / \mathrm{d}$ 와 $3 \%$ 구의 $2.09 \mathrm{gN} / \mathrm{d}$ 에 비해 높았다 $(\mathrm{p}<0.05)$.

본 연구에서 질소 섭취량의 증가는 두충 잎 대체구의 사료 섭취량이 증가(Table 2) 하였을 뿐만 아니라 두충 잎의 조단백질 함량 $(19.53 \%)$ 이 볏짚의 조단백질 함량 $(4.22 \%)$ 보다 약 3.6 배 정도 높음(Table 1)에 기인한 것으로 생각된다. 또한 Hoover와 Stokes(1991)은 제 1위내 분해성 단백질(rumen degradable protein; RDP)의 양은 탄수화물의 소화에는 영향을 미치지는 않지만, 미 생물의 성장효율에는 크게 영향을 미치며, $\mathrm{RDP}$ 가 증가할수록 미생물의 성장효율이 증가한다 고 하였고, Stokes 등(1991)은 비구조탄수화물

Table 3. Effects of dietary substitution of Eucommia ulmoides leaves for rice straw on nitrogen balance and amount of microbial nitrogen synthesis of sheep

\begin{tabular}{|c|c|c|c|c|c|}
\hline \multirow{2}{*}{ Items } & \multicolumn{4}{|c|}{ Substituted levels (\%) of air dried Eucommia ulmoides leaves } & \multirow{2}{*}{ SEM } \\
\hline & 0 & 3 & 5 & 10 & \\
\hline Nitrogen intake $(\mathrm{g} / \mathrm{d})$ & $10.31^{\mathrm{b}}$ & $10.84^{\mathrm{b}}$ & $12.41^{\mathrm{a}}$ & $12.55^{\mathrm{a}}$ & 0.420 \\
\hline Fecal nitrogen $(\mathrm{g} / \mathrm{d})$ & $4.28^{\mathrm{a}}$ & $3.57^{\mathrm{b}}$ & $4.11^{\mathrm{ab}}$ & $4.43^{\mathrm{a}}$ & 0.215 \\
\hline Urine nitrogen $(\mathrm{g} / \mathrm{d})$ & $4.38^{\mathrm{a}}$ & $4.04^{\mathrm{ab}}$ & $3.65^{\mathrm{b}}$ & $3.33^{b}$ & 0.118 \\
\hline Retained nitrogen $(\mathrm{g} / \mathrm{d})$ & $1.64^{\mathrm{c}}$ & $3.23^{\mathrm{b}}$ & $4.65^{\mathrm{a}}$ & $4.79^{\mathrm{a}}$ & 0.389 \\
\hline $\mathrm{DOMI}^{1)}(\mathrm{g} \mathrm{DM} / \mathrm{d})$ & 639.38 & 628.87 & 643.46 & 630.62 & 5.479 \\
\hline OM digestibility (\%) & $41.54^{b}$ & $45.10^{\mathrm{a}}$ & $44.83^{\mathrm{a}}$ & $43.39^{\mathrm{ab}}$ & 0.981 \\
\hline $\mathrm{PD}^{2)}$ excretion $(\mathrm{mmol} / \mathrm{d})$ & $2.43^{\mathrm{b}}$ & $2.42^{\mathrm{b}}$ & $2.90^{\mathrm{a}}$ & $2.70^{\mathrm{ab}}$ & 0.102 \\
\hline Microbial nitrogen $(\mathrm{g} \mathrm{N} / \mathrm{d})$ & $2.11^{\mathrm{b}}$ & $2.09^{\mathrm{b}}$ & $2.51^{\mathrm{a}}$ & $2.33^{\mathrm{ab}}$ & 0.087 \\
\hline
\end{tabular}

1) DOMI : Digestible organic matter intake.

2) Total purine derivatives.

a, b, c Means with different superscripts in the same row differ significantly $(\mathrm{p}<0.05)$. 
(non-tructural carbohydrate; NSC)과 RDP의 비율 이 2:1일 때 제 1 위내 미생물체단백질이 가장 원활하게 합성된다고 하였으며, 사료내 $\mathrm{RDP}$ 의 함량은 $10 \sim 13 \%$, 총 탄수화물의 $56 \%$ 가 $\mathrm{NSC}$ 일 때 미생물체단백질 합성량이 최대로 증가한다 고 하였는데, 본 연구에서 두충 잎 대체 급여 구의 미생물체단백질 합성량이 증가한 것은 반 추위내에서 단백질 분해가 원활하게 이루어졌 고 반추위내 미생물체단백질 합성을 위한 질소 원이 풍부하게 공급되었을 뿐만 아니라 $\mathrm{NSC}$ 의 분해가 왕성하여 반추위내 미생물 성장을 위한 에너지원인 유기물의 이용효율이 증가되었기 때문인 것으로 생각된다.

따라서 질소 축적율, 유기물 이용율 및 반추 위내 미생물체단백질 합성량 개선을 위해 저질 조사료인 볏짚의 $5 \%$ 를 두충 잎으로 대체하여 급여하는 것이 양질 조사료의 확보 측면에서 매우 효과적일 것으로 생각된다.

그러나 일반적으로는 단백질 축적량이 증가 할수록 체내 아미노산 대사율과 암모니아 생성 량이 증가되어 뇨 배설량이 증가되는데, 본 연 구의 결과 두충 잎을 5 $10 \%$ 급여시 뇨 배설 량이 오히려 감소하므로 이에 대한 추가 연구 의 필요성이 절실하다고 생각한다.

\section{3. 반추위내 $\mathrm{pH}$ 변화와 total VFA 및 RAN 함량 변화}

두충 잎을 급여하는 조사료를 기준으로 0,3 , 5 및 $10 \%$ 대체한 사료를 면양에 급여하였을 때 시험사료의 반추위내 발효시간 $(0,0.5,1,2,4$ 및 8시간)에 따른 반추위 내용물의 $\mathrm{pH}$ 변화와 total VFA 및 RAN(ruminal ammonia nitrogen) 함 량 변화를 조사한 결과는 Fig. 1 같다.

반추위내 $\mathrm{pH}$ 의 경시적 변화는 대조구를 포 함한 모든 처리구에서 사료급여 후 1 시간까지 는 급격히 하락하였으며, 2 시간 이후에는 서서 히 증가하였다. 발효시간에 따른 $\mathrm{pH}$ 변화는 사 료급여 후 1 시간에는 대조구와 $5 \%$ 구 및 $10 \%$ 구는 각각 6.81 과 6.74 및 6.72 로 차이가 없었 으나 $3 \%$ 구는 6.66 으로 다른 처리구에 비해 낮 았다 $(\mathrm{p}<0.05)$. 사료급여 후 2 시간 이후에는 사 료급여 후 1 시간과 같은 경향이지만 대조구를
Fig. 1. The pattern of variation in ruminal $\mathrm{pH}$, ruminal concentrations of total VFA and RAN(ruminal ammonia-nitrogen) in sheep given diets containing different levels of substituted Eucommia ulmoides leaves for rice straw.

포함한 모든 처리구에서 유의차가 없었다. 반 추위내 RAN 함량의 경시적 변화는 대조구를 포 함한 모든 처리구에서 사료급여 후 0.5 시간과 1 시간 및 2 시간에 급격히 증가하였으며, 4 시간 이 후에는 서서히 감소하였다. 발효시간에 따른 RAN 의 변화는 사료급여 0.5 시간에는 $3 \%$ 구와 $5 \%$ 구 가 각각 $13.97 \mathrm{mg} / 100 \mathrm{ml}$ 과 $14.68 \mathrm{mg} / 100 \mathrm{ml}$ 로 대조구 와 $10 \%$ 구의 $11.45 \mathrm{mg} / 100 \mathrm{ml}$ 과 $12.03 \mathrm{mg} / 100 \mathrm{ml}$ 에 비해 증가하였다 $(\mathrm{p}<0.05)$. 이와 같은 경향은 사료 급여 후 1 시간까지 계속되었으며, 2 시간 후에는 두충 잎으로 대체한 모든 처리구에서 16.87 
$18.98 \mathrm{mg} / 100 \mathrm{ml}$ 로 대조구의 $12.02 \mathrm{mg} / 100 \mathrm{ml}$ 에 비 해 증가하였다 $(\mathrm{p}<0.05)$. 사료급여 4 시간 이후에 는 급격히 감소하는 경향이었다. 반추위내 total VFA 함량의 경시적 변화는 대조구를 포함한 모든 처리구에서 사료급여 후 0.5 시간에 급격 히 증가하였으며, 2 시간 이후에는 서서히 감소 하였다. 발효시간에 따른 total VFA의 변화는 사료급여 0.5 시간에 급격히 증가하여 두충 잎을 대체한 모든 처리구는 $10.29^{\sim} 10.37 \mathrm{mmol} / 100 \mathrm{ml}$ 로 대조구의 $9.98 \mathrm{mmol} / 100 \mathrm{ml}$ 에 비해 높았다 $(\mathrm{p}<0.05)$. 이와 같은 경향은 사료급여 1 시간까지 지속되 었다. 사료급여 2 시간까지는 급속히 감소하였 으며, 그 후에는 서서히 감소하였다.

이와 같은 결과에서 Oltjen 등(1968)은 반추위 액의 $\mathrm{pH}$ 는 반추위내 미생물에 의한 질소 화합 물의 빠른 가수분해로 인한 암모니아의 생성이 사료급여 후 1 2 시간에 증가한다고 하였다. 본 연구서는 두충 잎을 $5 \%$ 이상 다량 대체 급여시 사료급여 2 시간 이후 반추위내 $\mathrm{pH}$ 의 증가로 질 소화합물의 분해가 왕성하여 암모니아의 발생이 촉진되었기 때문인 것으로 생각된다. RAN 함량 은 반추위내에서 사료중 질소의 분해정도를 나 타내며 미생물에 의한 질소의 재 이용에 관여하 며(Siddons 등; 1985), Satter와 Slyter(1974)는 조 사료 급여시 미생물체단백질 합성을 최대로 유 지시키기 위해서는 RAN 함량이 $5 \mathrm{mg} / 100 \mathrm{ml}$ 이상 이어야 한다고 하였으며, Leng(1989)은 RAN 함 량이 $20 \mathrm{mg} / 100 \mathrm{ml}, \mathrm{Kim}$ 등(1993)은 $50 \mathrm{mg} / 100 \mathrm{ml}$ 으 로 높은 수준을 유지할 경우 건물 섭취량과 소 화율이 최대가 된다고 보고하여 연구자들간 다 소 차이를 보였다. 본 연구에서는 RAN 함량이 사료급여 전(0시간)에 대조구를 포함한 모든 처 리구에서 $9.02 \sim 10.30 \mathrm{mg} / 100 \mathrm{ml}$ 으로 미생물체단 백질 합성에 충분한 질소 공급량을 나타내었 을 것으로 생각된다. Sniffen과 Robinson(1987) 은 비구조성 탄수화물이 구조성 탄수화물에 비 해 발효가 빨리 일어나며, 가용성 당은 시간당 약 $300 \%$ 로 가장 빨리 분해가 일어나는 반면 구조성 탄수화물은 시간당 $3 \sim 4 \%$ 로 분해율이 낮아 전분에 비해 5 배 이상, 가용성 당에 비해 서는 30 배 이상 서서히 분해가 일어난다고 하 였다. 이와 같은 이론에 근거할 때 본 연구에 서는 두충 잎을 대체 급여함으로 대조구에 비 해 많은 양의 비구조성 탄수화물이 신속하게
분해되었기 때문에 사료급여 후 0.5 시간과 1 시간에 두충 잎 대체구의 total VFA 함량이 대 조구에 비해 높았던 것으로 생각된다.

이와 같은 결과, 본 연구에서 반추위내에서 의 발효작용은 사료급여 후 0.5 시간에 활발하 게 일어나기 시작하여 사료급여 후 2 시간 까 지 계속되며, 그 후에는 서서히 감소하는 것을 확인할 수 있었다. 또한 두충 잎을 대체하여 급여할 경우 반추위내 미생물의 작용 촉진 또 는 반추위내 발효조건을 개선시켜 발효작용이 더욱 활발하게 일어나는 것을 확인할 수 있었 으며, 특히 두충 잎을 $5 \sim 10 \%$ 대체 급여할 경 우 그 효과가 가장 높을 것으로 생각된다.

$$
\text { IV. 요 약 }
$$

본 시험은 두충 잎을 저질 조사료인 볏짚의 일부로 대체.이용할 목적으로 평균체중 $50.2 \pm$ $1.6 \mathrm{~kg}$ 의 건강한 숫 면양(Corriedale $\times$ Polwarth) 4 두로 $4 \times 4$ 라틴 방각법으로 실시하였으며, 이때 농후사료 : 조사료의 비율은 $3: 7$ 이었다. 시험 구는 두충을 대체하지 않은 대조구와 조사료인 볏짚의 건물을 기준으로 음건 두충 잎을 3,5 및 $10 \%$ 대체한 4 개 처리구를 공시하였으며, 영양소 이용율, 기호성, 반추위 내 발효 특성 및 미생물 체단백질 합성량을 조사.분석하였다. 조지방 소화율은 3\% 구와 5\% 구가 대조구에 비하여 약 $12.5 \sim 17.5 \%$ 로 증가하였다 $(\mathrm{p}<0.05)$. 조섬유 소화 율은 두충잎을 대체한 모든 처리구가 대조구에 비하여 약 $10.6 \sim 13.7 \%$ 로 개선되었다 $(\mathrm{p}<0.05)$. 건 물 섭취량은 $10 \%$ 구가 $844 \mathrm{~g}$ 으로 가장 많았으며 $5 \%$ 구는 그 다음으로 많이 섭취하였으며, 대조 구와 $3 \%$ 구는 가장 낮았다 $(\mathrm{p}<0.05)$. 질소 축적량 은 $3 \%$ 구가 대조구에 비하여 약 $97 \%$ 가 개선되 었으며, $5 \%$ 구와 $10 \%$ 구가 약 $173 \sim 192 \%$ 가 개 선되었다 $(\mathrm{p}<0.05)$. 유기물 이용율은 $3 \%$ 구와 $5 \%$ 구가 대조구에 비해 높았다 $(\mathrm{p}<0.05) . \mathrm{PD}$ (purine derivatives) 배설량은 $5 \%$ 구가 $2.90 \mathrm{mmol} / \mathrm{d}$ 로 대 조구와 $3 \%$ 구에 비하여 높았다 $(\mathrm{p}<0.05)$. 미생물 체단백질 합성량은 $5 \%$ 구가 $2.51 \mathrm{gN} / \mathrm{d}$ 로 대조구 와 $3 \%$ 구에 비하여 높았다 $(\mathrm{p}<0.05)$. 반추위내 total VFA 함량은 두충 잎 처리구에서 높게 나 타났다. RAN 함량은 두충 잎 급여 후 $1 \sim 4$ 시간 에 $15 \sim 19 \mathrm{mg} / 100 \mathrm{ml}$ 로 높게 유지되었다. 
이상의 결과를 종합하면, 두충 잎을 음건하 여 반추동물에게 $5 \sim 10 \%$ 를 대체하여 급여할 경우 영양소 소화율, 기호성 및 반추위 내 발 효조건 개선에 유리할 것으로 생각된다.

\section{$\mathrm{V}$. 인 용 문 헌}

1. AOAC. 1990. Official method of analysis, Association of Official Agricultural Chemists. Washington, D. C. USA.

2. Bergmer, H. U. 1974. Methods of enzymatic analysis. Academic Press. New York. USA. p. 84.

3. Chen, X. B. and Gomes, M. J. 1995. Estimation of microbial protein supply to sheep and cattle based on urinary excretion of purine derivatives : An overview of the technical details. Rowett Res. Ins.

4. Deyama, T., Ikawa, T., Kitagawa, S. and Nishibe, S. 1987. The constituents of Eucommia ulmoides Oliv VI. Isolation of a new sesquilignan and neolignam glycoside. Chem. Pharm. Bull. 35:1803.

5. Duncan, D. B. 1955. Multiple range and multiple F tests. Biometrics. 11: 1 .

6. Fenner, H. and Elliot, J. M. 1963. Quantitative method for determining the steam volatile fatty acid in the rumen fluid by gas chromatography. J. Anim. Sci. 22:624.

7. Hoover, W. and Stokes, S. 1991. Balancing carbohydrates and proteins for optimum rumen microbial yield. J. Dairy Sci. 74:3630.

8. Hu, S. Y. A. 1978. Contribution to our knowledge of Tu-Chung-Eucommia ulmoides, American J. Chinese Med. 7:5.

9. Hwang, W. K., Choi, S. B. and Kim, I. H. 1996. Physiological activities of mixed extracts of Acantopancis senticosi radicis cortex and Eucommiae cortex. Kor J. Pharmacogn. 27:65.

10. Kim, J. H., Yokota, H., Ko, Y. D., Okajima, T. and Ohshima, M. 1993. Nutritional quality of whole crop corn forage ensiled with cage layer manure. II. In situ degradability and fermentation characteristics in the rumen of goats. Asian-Aus. J. Anim. Sci. 6:53.

11. Kimura, Y., Okuda, H., Okuda, T., Hatano, T., Agata, I. and Arichi, S. 1985. Studies on the activities of tannins and related compounds from medicinal plants and drug. VII. Effects of extracts of leaves of Artemisia, species and caffeic acid and chlorogenic acid on lipid metabolic injury in rats fed peroxidixed oil. Chem. Pharm. Bull. 33:2028.
12. Leng, R. A. 1989. In ruminant physiology and nutrition in Asia(Eds. C. Devendra and E. Imaizumi). Jap. Soc. of Zootech. Sci.

13. Metroi, K., Furutsu, M. and Takahashi. S. 1997. The prevention effect of ginseng with Du-Zhung leaf on protein metabolism in aging. Biol. Pharm. Bull., 20:237.

14. Nakasa, T., Yamaguchi, M., Okinaka, O. and Metori, K. 1995. Effect of Du-chung leaf extract on plasma and hepatic lipids in rats fed on a high fat plus high cholesterol diet. Nippon Nogeikagaku Kaishi. 69:1491.

15. Oltjen, R. R., Slyter, L. L., Kozak, A. S. and Williams, E. E. jr. 1968. Evaluation of urea, biuret, urea phosphate and uric acid as NPN sources for cattle. J. Nutr. 94:193.

16. SAS. 1990. SAS/STAT Software for PC. Release 6.11, SAS Institute, Cary, NC, U.S.A.

17. Satter, L. D. and Slyter, L. L. 1974. Effect of ammonia concentration on rumen microbial protein production in vitro. Br. J. Nutr. 32:199.

18. Siddons, R. C., Paradine, J., Gale, D. L. and Evans, R. T. 1985. Estimation of the degradability of dietary protein in the sheep rumen by in vivo and in vitro procedures. Br. J. Nutr. 54:545.

19. Sniffen, C. J. and Robinson, P. H. 1987. Microbial growth and flow as influenced by dietary manipulations. J. Dairy Sci. 70:425.

20. Stokes, S. R., Hoover, W. H., Miller, T. K. and Manski, R. P. 1991. Impact of carbohydrate and protein levels on bacterial metabolism in continuous culture. J. Dairy Sci. 74:860.

21. Tharib, S. M., Gnan, S. O. and Veitch, G. D. A. 1983. Antimicrobial activity of compounds from Artemisia campestris. J. Food Protection. 46:185.

22. Van Soest, P. J., Roberts, J. B. and Lewis, B. A. 1991. Methods for dietary fiber, neutral detergent fiber, and non-starch polysaccharides in relation to animal nutrition. J. Dairy Sci. 74: 3583.

23. 森本. 1971. 動物營養實驗法. 養賢堂. 日本.

24. 김영민. 2005. 두충의 반추동물 사료개발에 관한 연구. 경상대학교 박사학위논문.

25. 맹원재. 1998. 반추동물영양학 : 반추위 미생물과 소화작용. 향문사. p 128.

26. 박성진, 김만배. 1996. 두충잎의 첨가가 육계의 성장 및 육질에 미치는 영향. 한국가금학회지. 23:71.

(접수일자 : 2005. 8. 19. / 채택일자 : 2005. 11. 18.) 